\title{
INFLUENCE OF WAITING TIME AFTER INSERTION OF BASE CHAMBER INTO SOIL ON PRODUCED GREENHOUSE GAS FLUXES
}

\author{
Cristina Muñoz $^{*}$, Surinder Saggar ${ }^{2}$, Peter Berben², Donna Giltrap ${ }^{2}$, and Neha Jha ${ }^{3}$
}

The soil chamber technique is most commonly used for measuring gas exchange between soil surfaces and the atmosphere, to understand regulatory processes relevant to determine the greenhouse gas (GHG) emissions from soils and to improve the emissions inventory of agricultural systems. The chambers are inserted into the soil to avoid the lateral diffusion of the gases. However, soil disturbance caused by chamber insertion causes in degassing and can result in erroneous flux data from measurements made immediately following chamber insertion. Here we assess the effect of soil disturbance associated with the insertion of the chambers on nitrous oxide $\left(\mathrm{N}_{2} \mathrm{O}\right)$ and methane $\left(\mathrm{CH}_{4}\right)$ fluxes with and without $\mathrm{N}$ fertilization, from a New Zealand pasture soil. We collected gas samples from the chambers at 0, 2, 4, 24, 96 and $168 \mathrm{~h}$ after chambers insertion. Our results show elevated levels of $\mathrm{N}_{2} \mathrm{O}$ inside the chambers ( 1.7 fold those of atmospheric concentrations outside the chambers) and greater fluxes within the first $4 \mathrm{~h}$ of installation compared to the values observed at $24 \mathrm{~h}$ and later; and negative $\mathrm{CH}_{4}$ flux in the same time period, but near to zero after $24 \mathrm{~h}$. Our results suggest that for accurate measurement of gas fluxes, measurements should be taken after $24 \mathrm{~h}$ of chambers installation to avoid the degassing effect.

Key words: Nitrous oxide, methane, agricultural soil, soil biological processes, gases monitoring.

$I^{n}$ situ measurements of greenhouse gas (GHG) emissions from soils are crucial to improve the GHG inventories of the countries that are required to develop their independent emission factors (EFs). Diverse tools and methods are used to determine carbon dioxide $\left(\mathrm{CO}_{2}\right)$, nitrous oxide $\left(\mathrm{N}_{2} \mathrm{O}\right)$, and methane $\left(\mathrm{CH}_{4}\right)$ fluxes from a specific site or farm-scale. These include the use of default EFs recommended by the Intergovernmental Panel on Climate Change (IPCC, 2007), measurements using chambers and micrometeorological approaches and modeling emissions (Saggar et al., 2009). The soil chambers are the most commonly used techniques for measuring gas exchange between soil surfaces and the atmosphere in diverse ecosystems and agricultural systems in countries all over the world (Rochette and EriksenHamel, 2008). This approach is essential to capture the highly variable - in space and time - emissions resulting from uneven excretal-N inputs and the episodic nature of the emissions, and to understand regulatory processes (Saggar et al., 2009). Chambers are containers (cylinders or boxes) randomly inserted into the soil to form an air-

${ }^{1}$ Universidad de Concepción, Facultad de Agronomía, P.O. Box 537, Chillán, Chile. "Corresponding author (cristinamunoz@udec.cl).

${ }^{2}$ Landcare Research, Private Bag 11052, Palmerston North, New Zealand.

${ }^{3}$ Massey University, Institute of Natural Resources, Palmerston North, New Zealand.

Received: 27 April 2011.

Accepted: 29 September 2011 tight soil enclosure. The insertion of the chamber into the soil avoids the leakage or gas contamination by lateral diffusion. Gas fluxes are monitored after temporarily sealing the chambers with a gas-tight seal using selflocking lids and greased O-ring. Chamber technique is based on an increase in gas concentration within the enclosed headspace and the concentration in the headspace is precisely determined by gas chromatography (Hedley et al., 2006). Gas fluxes are calculated using a linear or non linear regression with the increase of the gas concentration with time. A minimum of three discrete air samples are required to check the linear or non-linear increase in gas concentration within the chamber headspace (Rochette and Eriksen-Hamel, 2008). This technique contributes to the understanding of the magnitude and spatiotemporal variability of GHG fluxes (Saggar et al., 2008).

Despite this technique being used extensively little research has been conducted on the effect of the soil disturbance caused by the insertion of the chamber, except that reported by Matthias et al. (1980). They indicated the soil disturbance resulting from chamber insertion caused an increase in the $\mathrm{N}_{2} \mathrm{O}$ flux and this increase in flux was indirectly proportional to the diameter of the chamber. Also a minimum set of criteria established for chamber technique by Rochette and Eriksen-Hamel (2008), from the review of chamber studies conducted in different parts of the world, does not include the wait time in gas collecting after the insertion of the chamber base. Furthermore, among other factors, the gaseous 
concentrations in the soil and their fluxes can be strongly influenced by $\mathrm{N}$ inputs (Saggar et al., 2004; Gregorich et al., 2005; Jones et al., 2005; Chu et al., 2007). It is necessary to include the $\mathrm{N}$ fertilization influence on the GHG fluxes caused by soil disturbance during the insertion of the chamber. The objectives of this study were to determine: i) the effect of the influence of chamber insertion and the equilibration time for collection of gas samples following the disturbance, and ii) their effect on $\mathrm{N}_{2} \mathrm{O}$ and $\mathrm{CH}_{4}$ emission from a pasture soil with and without $\mathrm{N}$ fertilizer input.

\section{MATERIALS AND METHODS}

\section{Site}

The experiment was conducted under the temperate climate in Manawatu-Wanganui Region, in the North Island of New Zealand. The soil at this site is an Argillicfragic Perch-gley Pallic, Tokomaru silt loam (Hewitt, 1992) (Dairy 4 Farm), Turitea Campus of Massey University, Palmerston North (40²1', 175'39'). The average rainfall is $969 \mathrm{~mm}$ (from 1970 to 2005) and the mean annual air temperature is $12.8^{\circ} \mathrm{C}$. The productive system in this soil is a commercial dairy farm of legumebased pastures.

\section{Experimental method}

Two treatments with 12 replicates represented two levels of $\mathrm{N}$ (control and $50 \mathrm{~kg} \mathrm{~N} \mathrm{ha-1}$ applied as potassium nitrate). Twenty-four plots $(1 \mathrm{~m} \times 1 \mathrm{~m})$ were established. Calculated amount of $\mathrm{KNO}_{3}$ was dissolved in water and applied in $\mathrm{N}$ treatments.

Static chambers (Ø $250 \mathrm{~mm}, 300 \mathrm{~mm}$ high) (Saggar et al., 2004), were inserted into the soil. A slot was cut into the soil with a sharp knife along the outer diameter of the chamber and the chamber was then pushed into the soil to a depth of $10 \mathrm{~cm}$ by hammering.

To evaluate the time of the influence of soil disturbance on GHG fluxes following chamber installation gas samples were collected immediately and after 2, 4, 24, 96, and $168 \mathrm{~h}$ using the methodology proposed by Hedley et al. (2006). Each time chambers were closed with the lid. After sealing, the headspace air was mixed by a $60 \mathrm{~mL}$ polypropylene syringe fitted with 3-way stopcock and then three gas samples were taken at times $\mathrm{t}_{0}, \mathrm{t}_{30}$ and $\mathrm{t}_{60}(30-\mathrm{min}$ intervals) from the headspace of each chamber. Following the last sampling $\left(t_{60}\right)$ the chambers were opened to allow them to equilibrate with the atmospheric concentration for the next sampling. Additionally, two ambient air samples were collected from the field at each gas sampling day and used as reference to determine the atmospheric gas concentration. The air temperature within the chamber was also measured using a digital thermometer. Once in the laboratory, $25 \mathrm{~mL}$ of the collected gas samples were transferred to a 12-mL- evacuated vial (Exetainer, Labco, England) that was held in over-pressure.
The gas samples were analyzed using a gas chromatograph (Shimadzu, GC 2010, Kyoto, Japan) equipped with a ${ }^{63} \mathrm{Ni}$-electron capture detector (ECD) and a flame ionization detector (FID) with methanizer. Nitrogen (99.99\% purity) was used as carrier gas and a makeup gas of 5\% methane in argon for ECD. In the case of $\mathrm{CH}_{4}$ analysis, $\mathrm{N}$ was used as carrier, while hydrogen (99.99\% purity) and synthetic air (99.99\% purity) were used for generating the combustion. A standard calibration curve was obtained using standards that covered the range of gas sample concentrations analyzed and that were run every 15 samples to check accuracy. The average rate of change in gas concentration was determined using either linear or non-linear regression, and gas-fluxes were then calculated from Equation [1] using the ideal gas law as described in Saggar et al. (2009):

$$
F=p \frac{V}{A} \frac{\Delta c}{\Delta t} \frac{273}{(T+273)}
$$

where $\mathrm{F}$ is the gas-flux $\left(\mu \mathrm{g} \mathrm{m}^{-2} \mathrm{~h}^{-1}\right), p$ is the density of the gas $\left(\mathrm{g} \mathrm{m}^{-3}\right), \mathrm{V}$ is the volume of the chamber $\left(\mathrm{m}^{3}\right), \mathrm{A}$ is the area of the chamber $\left(\mathrm{m}^{2}\right), \Delta c / \Delta t$ is the average rate of change of concentration with time $\left(\mathrm{mg} \mathrm{L}^{-1} \mathrm{~h}^{-1}\right)$, and $\mathrm{T}$ is the temperature $\left({ }^{\circ} \mathrm{C}\right)$ in the chamber.

The soil water content was measured at each time of sampling, and expressed as gravimetric water fraction relative to oven dried (at $105^{\circ} \mathrm{C}$ ) soil.

\section{Statistical analysis}

A complete randomized factorial design 2 (treatments) $\times$ 6 (times) was used to analyze the data. A non-parametric analysis of Kruskal Wallis $(\mathrm{p} \leq 0.05)$ and its corresponding Conover post hoc test (Conover and Iman, 1981; Conover, 1999) with a $95 \%$ confidence interval ( $p \leq 0.05)$. The Conover test allows conducting pairwise comparisons between the means of the ranks of the treatments and/or contrasts between them.

\section{RESULTS AND DISCUSSION}

The soil water content in the $0-10 \mathrm{~cm}$ depth in all plots during this field study was $23 \pm 5 \%$. Figures 1 and 2 show the time zero $\left(\mathrm{t}_{0}\right)$ concentrations of $\mathrm{N}_{2} \mathrm{O}$ and $\mathrm{CH}_{4}$ in gas samples collected immediately after closing the chambers at $0,2,4,24,96$, and $168 \mathrm{~h}$ of inserting the chambers in the soil in both the control and $\mathrm{N}$ fertilized treatment plots. The concentrations of $\mathrm{N}_{2} \mathrm{O}$ within the chambers during the initial period ( 0 to $4 \mathrm{~h} ; 498 \pm 18$ $\left.\mu \mathrm{g} \mathrm{L}^{-1}\right)$ were almost twice to those measured (285 \pm $18 \mu \mathrm{g} \mathrm{L}^{-1}$ ) between 24 and $168 \mathrm{~h}$ of chamber insertion, while the atmospheric concentrations (outside the chambers) over the whole sampling period of this study were $292 \pm 21 \mu \mathrm{g} \mathrm{L}^{-1}$. These high initial chamber $\mathrm{N}_{2} \mathrm{O}$ concentrations appear to be the result of the degassing of $\mathrm{N}_{2} \mathrm{O}$ from the disturbed soil caused by chamber insertion into the soil. 


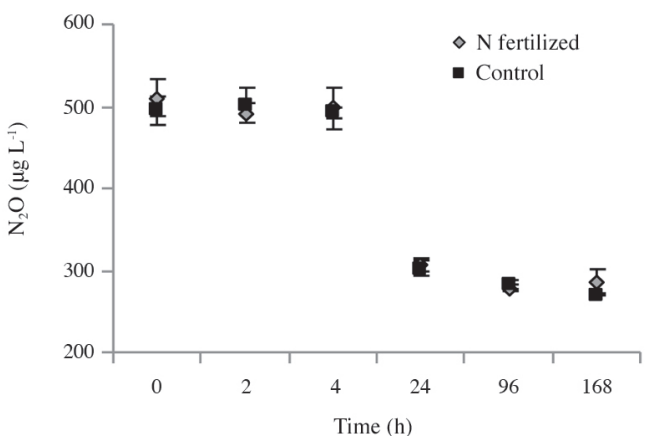

\begin{tabular}{|c|c|c|}
\hline Time & $\mathrm{N}$ fertilized & Control \\
\hline & & \\
\hline 0 & $510.32 \mathrm{a}$ & $494.87 \mathrm{a}$ \\
\hline 2 & $491.42 \mathrm{a}$ & $498.95 a$ \\
\hline 4 & $494.41 \mathrm{a}$ & $491.40 \mathrm{a}$ \\
\hline 24 & $306.93 b$ & $302.07 \mathrm{~b}$ \\
\hline 96 & $277.74 \mathrm{~b}$ & $282.93 \mathrm{bc}$ \\
\hline 168 & $284.89 \mathrm{~b}$ & $270.01 \mathrm{c}$ \\
\hline
\end{tabular}

Figure 1. Initial concentration of $\mathrm{N}_{2} \mathrm{O}$ inside the chamber at different times after the base chamber insertion in a field experiment (Conover, $\mathrm{p} \leq \mathbf{0 . 0 5}$ ).

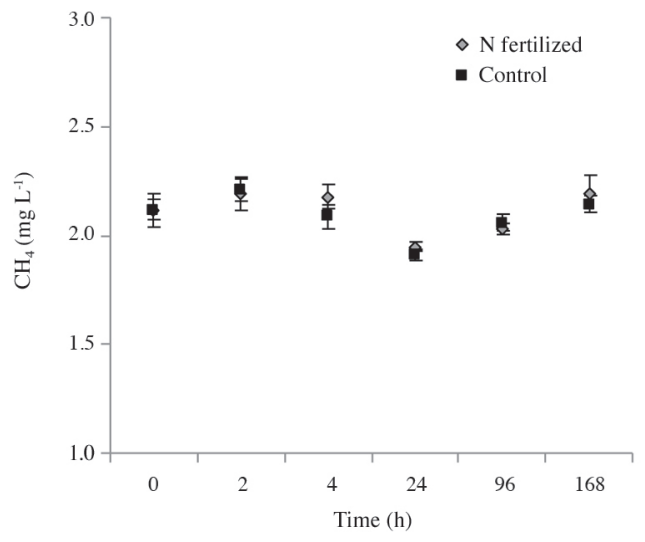

\begin{tabular}{|c|c|c|}
\hline Time & $\mathrm{N}$ fertilized & Control \\
\hline & $\bar{Z}$ & 211 \\
\hline 0 & 2.12ab & 2.11ab \\
\hline 2 & $2.19 \mathrm{a}$ & $2.21 \mathrm{a}$ \\
\hline 4 & $2.18 \mathrm{a}$ & $2.09 \mathrm{~b}$ \\
\hline 24 & $1.95 \mathrm{c}$ & $1.91 \mathrm{c}$ \\
\hline 96 & $2.03 b c$ & $2.06 \mathrm{~b}$ \\
\hline 168 & $2.20 \mathrm{a}$ & $2.14 \mathrm{ab}$ \\
\hline
\end{tabular}

Figure 2. Initial concentration of $\mathrm{CH}_{4}$ inside the chamber at different times after the base chamber insertion in a field experiment (Conover, $\mathrm{p} \leq \mathbf{0 . 0 5}$ ).

The concentration of $\mathrm{CH}_{4}$ within the chambers at $\mathrm{t}_{0}\left(2.10 \pm 0.13 \mathrm{mg} \mathrm{L}^{-1}\right)$ was slightly higher than the atmospheric concentrations (outside the chambers, 1.81 $\left.\pm 0.05 \mathrm{mg} \mathrm{L}^{-1}\right)$. The chamber concentrations measured at $\mathrm{t}_{0}$ for the remaining period also did not differ from the atmospheric concentrations. The similarity in $\mathrm{CH}_{4}$ concentrations between the chambers and the atmosphere seems to be the due to aerobic soil conditions resulting in little $\mathrm{CH}_{4}$ accumulation and little degassing during chamber insertion.
Fluxes of $\mathrm{N}_{2} \mathrm{O}$ and $\mathrm{CH}_{4}$ are shown in Figures 3 and 4. The $\mathrm{N}_{2} \mathrm{O}$ fluxes from the control were generally low $\mathrm{N}_{2} \mathrm{O}$ fluxes $\left(0-0.05 \mathrm{mg} \mathrm{N} \mathrm{m}^{-2} \mathrm{~h}^{-1}\right)$. These fluxes were, however, significantly higher during the initial $0-24 \mathrm{~h}$ measurement period than those obtained after $24 \mathrm{~h}(0.01 \pm 0.002 \mathrm{mg} \mathrm{N}$ $\mathrm{m}^{-2} \mathrm{~h}^{-1}$ ) of chamber insertion. In the $\mathrm{N}$ fertilizer treatment the fluxes were much higher $\left(0-0.30 \mathrm{mg} \mathrm{N} \mathrm{m}^{-2} \mathrm{~h}^{-1}\right)$ than the control. However, the pattern of fluxes between the 0-24 $\mathrm{h}\left(0.19 \pm 0.08 \mathrm{mg} \mathrm{N} \mathrm{m}^{-2} \mathrm{~h}^{-1}\right)$ and after $24 \mathrm{~h}$ periods $(0.03$ $\pm 0.01 \mathrm{mg} \mathrm{N} \mathrm{m}^{-2} \mathrm{~h}^{-1}$ ) was similar to that observed in the control. The differences in fluxes in both the treatments appear to be resulting from a relevant impact of disturbance caused by inserting the chambers. $\mathrm{CH}_{4}$ fluxes slightly fluctuated between negative (methane consumption) and zero (neither consumption nor production) during the measurement period under these aerobic soil conditions (Figure 4). Negative $\mathrm{CH}_{4}$ flux values were obtained only between 0 to $4 \mathrm{~h}$ after chamber insertion when the gas fluxes were in the range of -0.01 to $-0.02 \mathrm{mg} \mathrm{CH}_{4}-\mathrm{C} \mathrm{m}^{-2}$ $\mathrm{h}^{-1}$ for both the control and $\mathrm{N}$ fertilized treatments, which could be the result of a stimulation of the methanotrophs microorganisms due to soil disturbance. After $24 \mathrm{~h}$, the $\mathrm{CH}_{4}$ flux was close to zero, with no statistical differences $(\mathrm{p} \leq 0.05)$ between the treatments. However, Saggar et al. (2008) indicated different levels of $\mathrm{CH}_{4}$ consume (or negative fluxes) in different land management systems

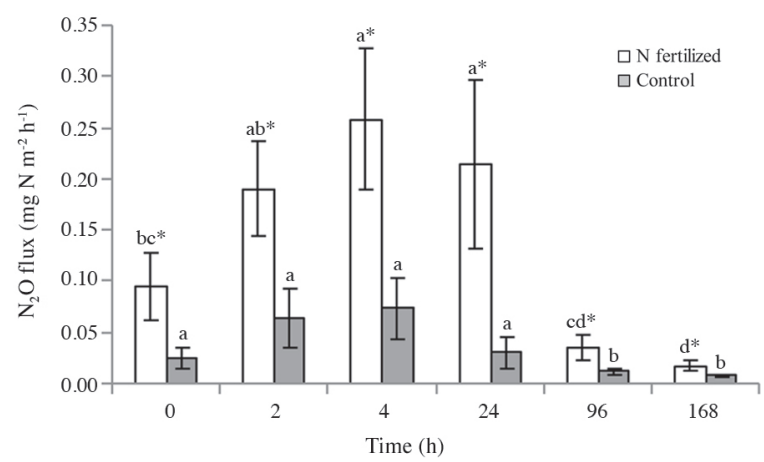

* Statistical difference between the pair of data ( $\mathrm{N}$ fertilized and control) at each gas sampling. Letters indicate statistical difference between each gas sampling.

Figure 3. $\mathrm{N}_{2} \mathrm{O}$ fluxes in a pasture soil with $\mathrm{N}$ fertilization and a control soil (Conover, $\mathrm{p} \leq \mathbf{0 . 0 5}$ ).

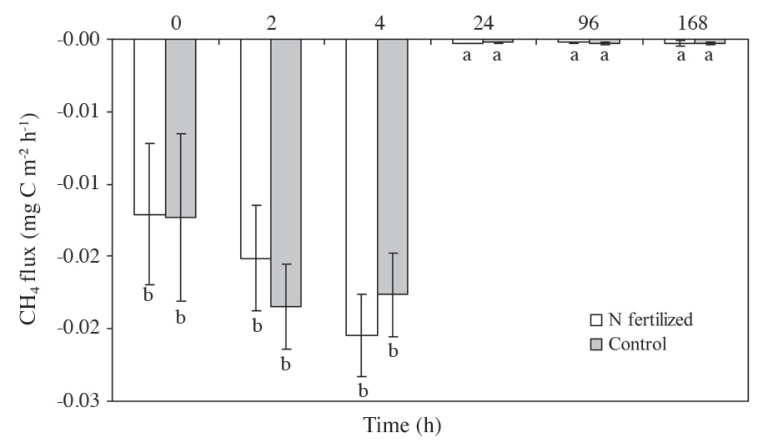

Letters show statistical differences between each gas sampling (Conover, $\mathrm{p} \leq 0.05$ ).

Figure 4. $\mathrm{CH}_{4}$ fluxes in a pasture soil with $\mathrm{N}$ fertilization and a control soil. 
in New Zealand, determining a seasonal pattern of soil methane sink in pastoral soils. In other agricultural systems, negative fluxes were obtained by Gregorich et al. (2005), but they indicate that the $\mathrm{CH}_{4}$ uptake from cultivated soils plays a minor role in atmospheric loading of GHG in relation to other sources/sinks. The $\mathrm{CH}_{4}$ fluxes do not seem to be affected by fertilization practice, since similar $\mathrm{CH}_{4}$ flux values were obtained in both treatments ( $\mathrm{N}$ fertilized and control treatments), same as the results obtained by Metay et al. (2007) in an clayey Oxisol in Brazil.

The results indicate that chamber insertion causes soil disturbance resulting in immediate degassing of $\mathrm{N}_{2} \mathrm{O}$ stored within the soil. Higher initial $\mathrm{t}_{0} \mathrm{~N}_{2} \mathrm{O}$ concentrations in the chambers than the atmospheric concentrations in the field obtained during the initial $24 \mathrm{~h}$ sampling period produce artificially high $\mathrm{N}_{2} \mathrm{O}$ fluxes, obtaining in the first $24 \mathrm{~h} 5$ fold higher $\mathrm{N}_{2} \mathrm{O}$ fluxes than after $96 \mathrm{~h}$ after chamber insertion in non- $\mathrm{N}$ fertilized soils, and 7 fold higher the $\mathrm{N}_{2} \mathrm{O}$ fluxes in $\mathrm{N}$ fertilized soils, supporting our hypothesis of higher efflux being the result of soil disturbance. These concentrations were almost twice the atmospheric values but declined after $24 \mathrm{~h}$. These results suggest that $24 \mathrm{~h}$ were required for the disturbed soil to reach equilibrium in soil-atmosphere exchange of gases. Our results also show that these initial higher chamber concentrations also resulted in higher fluxes in the first $24 \mathrm{~h}$ after inserting the base chamber (Figure 3). Similarly, Matthias et al. (1980) indicate that the insertion of a metal cylinder from chambers into the soil ( $5 \mathrm{~cm}$ of depth) produce an increase $250 \%$ (in average) in the $\mathrm{N}_{2} \mathrm{O}$ emission rate from different sites of a Webster soil.

In the $\mathrm{N}$ fertilized plots, the higher initial levels of $\mathrm{N}_{2} \mathrm{O}$ flux could result from the combined effect of the soil disturbance and the nitrification/denitrification processes that occur fast after a fertilization event. These produce an increase of the $\mathrm{N}_{2} \mathrm{O}$ flux in the first time with a decrease afterwards. In this sense, Abbasi and Adams (2000) indicate that between $60 \%$ to $100 \%$ of the added $\mathrm{N}$ (applied as $\mathrm{KNO}_{3}$ ) disappeared from the soil mineral $\mathrm{N}$ pool over a 7-d period, with losses of $5-22 \mathrm{~kg} \mathrm{~N} \mathrm{ha}^{-1}$ as $\mathrm{N}_{2} \mathrm{O}$ in a compacted grassland soil.

The higher $\mathrm{N}_{2} \mathrm{O}$ fluxes in fertilizer plots compare to control soil, indicates the relevant impact of $\mathrm{N}$ input on $\mathrm{N}_{2} \mathrm{O}$ fluxes. Saggar et al. (2004) evaluated the $\mathrm{N}_{2} \mathrm{O}$ flux in a grazing system in the same soil (Diary 1 Farm), obtained an annual net emission of $2.5 \mathrm{~kg} \mathrm{~N}_{2} \mathrm{O}-\mathrm{N} \mathrm{ha}^{-1}$ (gas sample collection $24 \mathrm{~h}$ after the insertion of the chamber) in an ungrazed area, obtaining an increase to $10.4 \mathrm{~kg} \mathrm{~N} \mathrm{~N}_{2} \mathrm{O}-\mathrm{N}$ $\mathrm{ha}^{-1}$ in a grazed area.

It is seen that the higher initial fluxes of $\mathrm{N}_{2} \mathrm{O}$ and negative $\mathrm{CH}_{4}$ fluxes caused by soil disturbance reported in this study are not representative of the normal soilatmosphere exchange of gases and are biased by the chamber insertion. Thus these initial fluxes are erroneous and flawed. It is therefore suggested that for more accurate flux estimates the gas samples should be collected after 24-h chamber insertion.

\section{CONCLUSIONS}

The results of this study show that efflux of $\mathrm{N}_{2} \mathrm{O}$ and $\mathrm{CH}_{4}$ from the soil is influenced by the soil disturbance caused during the insertion of chambers into the soil. The differences in $\mathrm{N}_{2} \mathrm{O}$ concentration in gas samples collected within the first $4 \mathrm{~h}$ of inserting the chamber into the soil was significantly higher than both the atmospheric concentrations and those measured after 24 $\mathrm{h}$ of chamber installation in fertilized and not fertilizer soil. These high initial chamber concentrations also resulted in very high and erroneous flux values. These results suggest that an equilibration period of $24 \mathrm{~h}$ is needed before the measurements are made to avoid erroneous results.

\section{ACKNOWLEDGEMENTS}

The authors thank the Livestock Emissions \& Abatement Research Network (LEARN) Post-doctoral Fellowships and FONDECYT Project N ${ }^{\circ} 1080076$.

Influencia del tiempo de espera después de la inserción de la base de la cámara en el suelo en los flujos de gases de efecto invernadero producidos. La técnica de la cámara es la más comúnmente usada para medir el intercambio de gases entre la superficie del suelo y la atmósfera, entender los procesos regulatorios relevantes para determinar las emisiones de gases de efecto invernadero (GHG) desde los suelos, y mejorar los inventarios de emisiones de sistemas agrícolas. Las cámaras se insertan en el suelo para evitar la difusión lateral de los gases. Sin embargo, la alteración en el suelo causada por la inserción de las cámaras causa pérdida de gases y puede resultar en datos de flujos erróneos desde las mediciones realizadas inmediatamente posteriores a la inserción de las cámaras. Determinamos el efecto de la alteración del suelo asociada con la inserción de las cámaras sobre los flujos de óxido nitroso $\left(\mathrm{N}_{2} \mathrm{O}\right)$ y metano $\left(\mathrm{CH}_{4}\right)$ con y sin fertilización nitrogenada, desde un suelo con pradera en Nueva Zelandia. Colectamos muestras gaseosas desde las cámaras a 0, 2, 4, 24, 96 y 168 h después de la inserción de las cámaras. Nuestros resultados muestran elevados niveles de $\mathrm{N}_{2} \mathrm{O}$ al interior de las cámaras $(1,7$ veces las concentraciones atmosféricas del exterior de las cámaras) y mayores flujos dentro de las primeras $4 \mathrm{~h}$ de instalación comparada a los valores observados a $24 \mathrm{~h}$ y posteriores; y flujos negativos de $\mathrm{CH}_{4}$ en el mismo período de tiempo, pero cercanos a cero después de $24 \mathrm{~h}$. Nuestros resultados sugieren que para la medida exacta de los flujos de gases, la medición debe ser tomada después de $24 \mathrm{~h}$ de la inserción de las cámaras para evitar el efecto de la liberación de gases.

Palabras clave: Óxido nitroso, metano, suelo agrícola, procesos biológicos del suelo, monitoreo de gases. 


\section{LITERATURE CITED}

Abbasi, M.K., and W.A. Adams. 2000. Gaseous N emission during simultaneous nitrification-denitrification associated with mineral $\mathrm{N}$ fertilization to a grassland soil under field conditions. Soil Biology and Biochemistry 32:1251-1259.

Chu, H., Y. Hosen, and K. Yagi. 2007. $\mathrm{NO}, \mathrm{N}_{2} \mathrm{O}, \mathrm{CH}_{4}$ and $\mathrm{CO}_{2}$ fluxes in winter barley field of Japanese Andisol as affected by $\mathrm{N}$ fertilizer management. Soil Biology and Biochemistry 39:330339.

Conover, W.J. 1999. Practical nonparametric statistics. John Wiley \& Sons, Inc., New York, USA.

Conover, W.J., and R.L. Iman. 1981. Rank Transformations as a bridge between parametric and nonparametric statistics. The American Statistician 35:124-133.

Gregorich, E.G., P. Rochette, A.J. VandenBygaart, and D.A. Angers. 2005. Greenhouse gas contributions of agricultural soils and potential mitigation practices in Eastern Canada. Soil and Tillage Research 83:53-72.

Hedley, C.B., S. Saggar, and K.R. Tate. 2006. Procedure for fast simultaneous analysis of the greenhouse gases: methane, carbon dioxide, and nitrous oxide in air samples. Communications in Soil Science and Plant Analysis 37:1501-1510.

Hewitt, A.E. 1992. New Zealand soil classification. DSIR Land Resources Scientific Report N¹9. 133 p.

IPCC. 2007. Climate change 2007: The physical science basis Summary for policymakers. Contribution of working group I to the fourth assessment report of the Intergovernmental Panel on Climate Change (IPCC). p. 1-18. In S. Solomon et al. (eds.) Cambridge University Press, Cambridge, UK.

Jones, S.K., R.M. Rees, U.M. Skiba, and B.C. Ball. 2005. Greenhouse gas emissions from a managed grassland. Global and Planetary Change 47:201-211.

Matthias, A.D., A.M. Blackmer, and J.M. Bremner. 1980. A simple chamber technique for field measurements of emissions of nitrous oxide from soils. Journal of Environmental Quality 9:251-256.

Metay, A., R. Oliver, E. Scopel, J.-M. Douzet, J.A. Alves, F. Maraux, et al. 2007. $\mathrm{N}_{2} \mathrm{O}$ and $\mathrm{CH}_{4}$ emissions from soils under conventional and no-till management practices in Goiânia (Cerrados, Brazil). Geoderma 141:78-88.

Rochette, P., and N. Eriksen-Hamel. 2008. Chamber measurements of soil nitrous oxide flux: are absolute values reliable? Soil Science Society of America Journal 72:331-342.

Saggar, S., R.M. Andrew, K.R. Tate, C.B. Hedley, N.J. Rodda, and J.A. Townsend. 2004. Modelling nitrous oxide emissions from dairy-grazed pastures. Nutrient Cycling in Agroecosystems 68:243-255.

Saggar, S., J. Luo, D.L. Giltrap, and M. Maddena. 2009. Nitrous oxide emissions from temperate grasslands: processes, measurements, modeling and mitigation. p. 1-66. In Sheldon, A.I., and E.P. Barnhart (eds.) Nitrous oxide emissions research progress. Environmental Science, Engineering and Technology Series. Nova Science Publishers, New York, USA.

Saggar, S., K.R. Tate, D.L. Giltrap, and J. Singh. 2008. Soilatmosphere exchange of nitrous oxide and methane in New Zealand terrestrial ecosystems and their mitigation options: a review. Plant and Soil 309:25-42. 